\title{
STABILISATION OF NIGER DELTA FAT CLAY WITH BLEND OF BINDERS FOR SUBGRADE APPLICATION - PART 1
}

\author{
F. M. Alayaki ${ }^{1,}{ }^{*}$, A. Al-Tabbaa ${ }^{2}$ and M. J. Ayotamuno ${ }^{3}$ \\ 1, Civil EngineEring DePartment, Federal University of Agriculture AbEokUta, Ogun State NigERIA \\ 2, ENGINEERING DEPARTMENT, UNIVERSITY OF CAMBRIDGE, UNITED KINGDOM

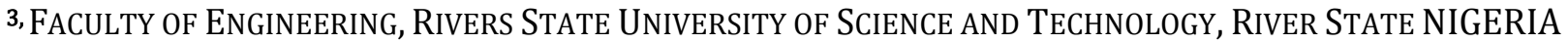 \\ E-mail addresses:1alayaafunmi@yahoo.com,2aa22@cam.ac.uk,3mjayotamuno@hotmail.com
}

\begin{abstract}
Construction of roads on fine-grained soils without any form of stabilisation is a major problem all over the world. In this study, a fat clay having poor subgrade rating (A-7-6) was mixed with blends of sand, drill cuttings ash (DCA), lateralite, and Portland Cement (PC) to improve its plasticity, California Bearing Ratio (CBR), and swell. The sand effected better particle grading of the clay and addition of PC increased its strength. Blends of DCA-PC and lateralite-PC effected friability, improved workability, and also increased the strength of the soil. Blends ratio: sand-PC (4:1); DCA-PC (1:1); and lateralite-PC (2:1) gave the best stabilising effect on the fat clay. The improvements noted were: plasticity index $<30$, soaked CBRvalues $>20 \%$ after 24 hours and $>10 \%$ after 96 hours, low swell ( $0.002-0.008 \%)$. Thus, this study revealed that the fat clay could be optimised for subgrade application using these stabilising additives.
\end{abstract}

Keywords: fat clay, CBR, swell, stabilization, plasticity

\section{INTRODUCTION}

Physical and chemical forms of soil stabilisation had been investigated in the Niger Delta, Nigeria because of the water-sensitivity of the soils and its adverse effect on pavements when used as construction materials. There is yet to be any respite to road failures in the region due to non-implementation of the investigation results. High quantities of additives and binders were recommended for the stabilisation of these problematic soils, which is unappealing for field application. Some of the previous researches are reviewed as follow:

According to [1], 10\% cement content caused an increase in unconfined compressive strength of marine clay (chicoco) from $55 \mathrm{kN} / \mathrm{m}^{2}$ to $124 \mathrm{kN} / \mathrm{m}^{2}$ while further increase in the cement content (up to 50\%) effected lower strength values. However, values for all the stabilised marine clay variants were greater than the unstabilised clay. Similar high cement quantity ranging from 8 to $12 \%$ was reported by [2] to obtain significant improvement in the CBR (up to $34 \%$ ) of weathered shale subgrade soils. The report given by [3] suggested that cement alone should not be used to stabilise fat clays especially those with liquid limit greater than $40 \%$ and plasticity index greater than 20 . The authors noted that very high quantity of cement is required to effect any significant change in the soil and which is not economically viable.

Report in[4]revealed that clay soil was blended with fine-grained sand in ratio $1: 1$ and then stabilise with cement. High strength reduction up to $40 \%$ was noted, when the stabilised mixture was soaked in water even with as much as $10 \%$ cement. The author then suggested that pavement constructed with the composite must be protected from water. [5] reported effect of cement on sandstone soils which consist of fine to medium sand fraction, 5 - 7\% silt, and average clay content of $50 \%$. Significant improvement in the density, shear strength, and soaked CBR (value up to 100\%) were noted, when about 8\% cement was used to stabilise soils. Furthermore, [6] also observed significantly improved densification and soaked CBR value of five cementstabilised deltaic soils. The soils which were majorly residues of tertiary sedimentary rock, were substantially improved when stabilised with sand and blends of sandcement. The soils stabilised with blend of $6 \%$ cement and $40 \%$ sand could be used as sub-base materials. The authors suggested that adequate compaction and sand stabilisation would be enough to stabilise these soils for subgrade application, while blends of sand and cement could be used to upgrade them to either sub-base or base materials. Stabilisation of soils derived from shale,

* Corresponding author, tel: +234-805-651- 1993 
which is particularly notorious for high clay content and lack of coarse aggregate was reported by [7]. Appreciable gradation improvement was noted when sand was added to augment particle size deficiency. Increase in strength was also observed when cement was added to the composite.

Literature in [8] revealed that the grading of the soil to be stabilised have influence on the strength gained. Well-graded soils were said to have a linear increase in Unconfined Compressive Strength (UCS) with increasing cement/lime content while uniformly graded soils do not have the linear behaviour when small quantity of cement or lime is used. The authors further reported the reactions between cement and soil particles: sand is assumed not to be involved in the chemical reaction with cement, and the precipitation of $\mathrm{Ca}(\mathrm{OH})_{2}$ crystals on the surface of sand grains do not appear detrimental. Silt particles act as a substrate for $\mathrm{Ca}(\mathrm{OH})_{2}$ to grow, thus removing it from further hydration reaction. This was said would result in initial reduction in strength of cement within 3 - 6 months. However, this may increase later at a longer time and may even be greater than the strength obtained from soils without silt. Furthermore, [9] noted that binders act as fillers rather than binders in poorly graded soils, and that silty soils are more difficult to stabilise because of their moisture sensitivity. The interaction between clay and cement was also assumed not to be detrimental, but clay with organic compounds may retard cement reaction, while highly cohesive clay may form clods or agglomerate rather than flocculate and may be difficult to mix. Linear increase in UCS was also reported for well-graded soils.

These reports from Niger Delta revealed that high quantities of cement and blends of cement and sand ( $>$ $10 \%$ for cement and $\sim 50 \%$ for sand) were used to stabilise the clayey soils. This would make application of the stabilised soils in pavement construction unrealistic. Therefore, this study investigated how to optimally use sand, DCA, lateralite, and cement in stabilising a fat clay soil for subgrade application. The sand was used to regrade the soil, DCA and lateralite were used to improve consistency and enhance bearing capacity, while cement was the binder. The binder and additives are available in the region.

\section{THE STUDY AREA}

The Niger Delta is situated in the southern part of Nigeria, bordered by the Atlantic Ocean to the south and Cameroon to the east. It covers an approximate 112,110 $\mathrm{km}$ surface area representing about $12 \%$ of Nigeria's total surface area [10]. There are nine of the Nigeria's constituent states in the region namely: Abia, Akwa Ibom, Bayelsa, Cross River, Delta, Edo, Imo, Ondo, and Rivers. The region has a tropical climate with two distinct wet and dry seasons. The mean annual rainfall usually exceeds $3500 \mathrm{~mm}$ along the coast and gradually decreases inland to about $2000 \mathrm{~mm}$, and annual mean temperature is between $18^{\circ} \mathrm{C}$ and $35^{\circ} \mathrm{C}$.This high rainfall usually results in widespread flooding, which may rise more than $5 \mathrm{~m}$ in some area and hence the high in-situ moisture content of foundation soils. The terrain in the region is flat at the coastal and deltaic plains which are to the south, but the northern part has a gently rolling and undulating landscape. The author specifically described the geologic units of the study area as back swamps, freshwater swamps, and meander belts. The major superficial soil type was described as light grey fine sand to silty clay [11]. The geological map of the study area is shown in Figure 1.

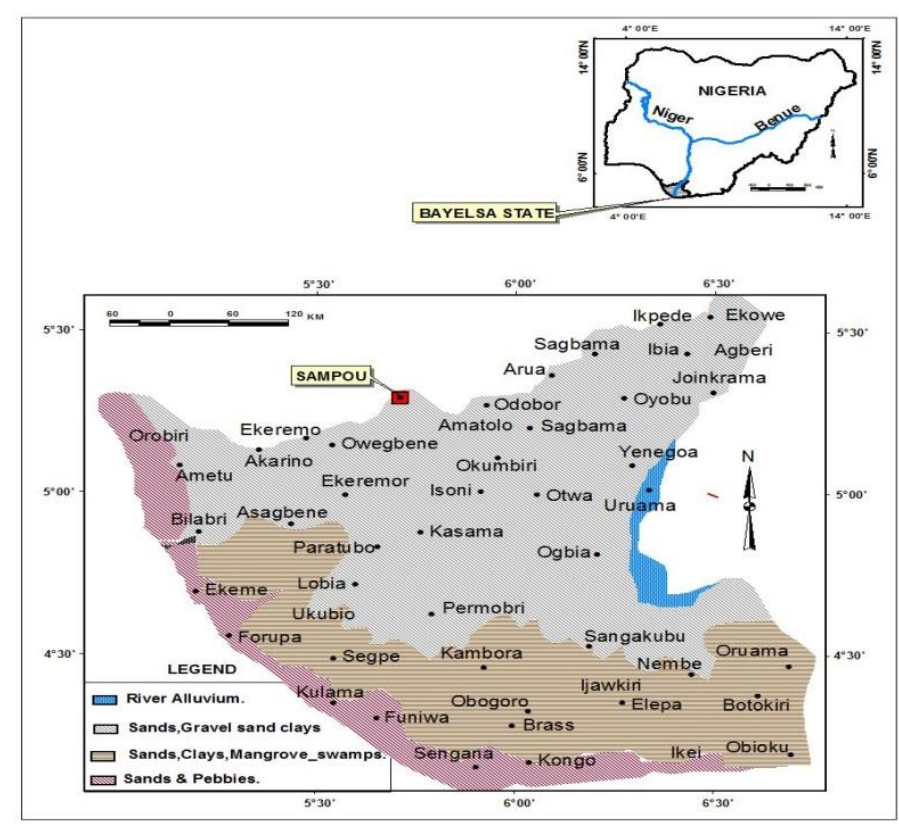

Figure 1: Digitised Geological map of Bayelsa state 


\section{MATERIALS AND METHODS}

\subsection{Materials}

The following materials were used in the study:

\subsubsection{Fat clay and Sand}

Both fat clay and sand samples were obtained from Sampou in Ekeremor Local Government Area of Bayelsa State. The fat clay was collected from the subgrade level of Odoni - Agbere road, while the sand was collected from a nearby borrow-pit. The site was swampy with water table almost at the ground surface. There was no form of stabilisation of the subgrade soils on this site, instead the problematic soil was excavated and massive filling to formation level was done using sands dredged from nearby rivers or borrow-pit which exist abundantly in the Niger Delta region.

\subsubsection{Cement}

Portland Limestone Cement (grade 42.5R) was obtained from Dangote Cement Plc. The physico-chemical properties are listed in Table 1.

\subsubsection{Drill cuttings ash (DCA)}

DCA was obtained from DEL Waste Management Company Limited in Onne Oil and Gas Free Zone, Rivers State. DCA is an industrial waste product that is yet to be fully exploited in terms of research and application especially in the Niger Delta. The region is naturally endowed with crude oil and its exploration is a very huge business for many international and local companies. DCA is the ash from thermal desorption of waste product of crude oil drilling operations. The waste is a mixture of drilling mud (type depends on the drilling company preference), base fluid (water, oil, or synthetic-oil), crude oil, crushed rocks and soils. The waste is treated by application of indirect heat at a very high temperature ( $>$ $300^{\circ} \mathrm{C}$ ) and the constituents are separated through grade-separation process. Some of the useful components are reclaimed and re-used in the drilling process. The solid residue flow out as the ash, and is either disposed-off in a designated landfill or stock-piled. This ash is generated in very large quantity and there is no useful adaptation for construction purposes. DCA is fine grained, silty textured, and could either be dark brown or grey in colour. The physico-chemical properties are listed in Table 1.

\subsubsection{Lateralite}

Lateralite is an innovative stabilising flux developed in Nigeria by[12]. The material is made up of different natural minerals, which were selected in definite proportions, heated to about $400^{\circ} \mathrm{C}$ and pulverised to very fine powder $(\sim 35 \mu \mathrm{m})$. This procedure enables the material to induce a pozzolanic reaction with the sesquioxides in fine-grained soils when mixed with water. The author reported that the bonding produced after air-drying was strong enough to make the stabilised soil impermeable when soaked in water. The physicochemical properties are listed in Table 1 . A view of the cement, additives, and the soil sample is presented in Figure 2.

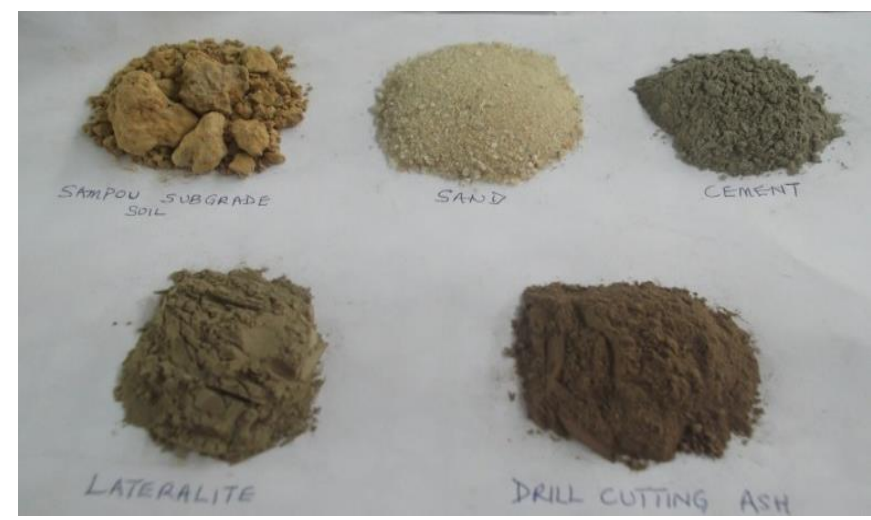

Figure 2: Soil sample, additives and binder used

\subsection{Methods:}

\subsubsection{Classification Characteristics}

The setting time of cement, DCA, and lateralite were analysed using vicat apparatus in accordance with [13]. Hydrogen ion concentration or the $\mathrm{pH}$ value was measured using $\mathrm{pH}$ meter. This involved the use of glass electrodes immersed in the additive suspension and were attached to the meter for measuring Electromagnetic Force (EMF) which is known to be related to $\mathrm{pH}$. The meter was calibrated using the $\mathrm{pH} 4,7$, and 10 buffer solutions. The oxides were determined using the energy dispersive X-ray fluorescence. The spectrometer was first calibrated and the correlation coefficient for the standard curve was 0.990 . Then about $5 \mathrm{~g}$ of the milled sample (about $5 \mu \mathrm{m}$ grain size) was used for the analysis.

The specific gravity and consistency limits test procedures as contained in [14] were also carried out. Air-dried sample was used instead of the prescribed oven-dried sample. This is because temperature at $105^{\circ} \mathrm{C}$ can effect much variation in tropical soils' properties [15]. Testing procedures contained in [16] were used for the stabilised soil. Liquid limit of the unstabilised and stabilised soil was determined by using the Casagrande apparatus. Fraction passing sieve $425 \mu \mathrm{m}$ was thoroughly mixed with distilled water for about 10 minutes at moisture content higher than the liquid limit and allowed to cure for at least 12 hours at room temperature before proceeding with the tests.

Particle size distribution is the grouping of soil's particles into separate sizes, and determination of each size 
portion by dry mass. $35 \mathrm{~g}$ of sodium hexametaphosphate and $7 \mathrm{~g}$ sodium carbonate dissolved in 1 litre distilled water was used to deflocculate the fat clay grains. The particles passing through sieve $63 \mu \mathrm{m}$ was carefully washed out and the soil retained on the sieve was oven dried. A set of sieve $(2.36 \mathrm{~mm}, 2.00 \mathrm{~mm}, 1.18 \mathrm{~mm}, 600 \mu \mathrm{m}$, $425 \mu \mathrm{m}, 300 \mu \mathrm{m}, 150 \mu \mathrm{m}$, and $63 \mu \mathrm{m})$ arranged in descending order was used to segregate the granular particles into sizes. The difference between original soil quantity and oven-dried washed quantity was taken as the silt and clay contents of the soils. The oven-dried washed clay was mixed with $10 \%$ sand and sieved to determine its effect on the soil gradation. The clean sand was also sieved without washing.

\subsubsection{Compaction and Strength Tests}

West African compactive effort [17]was used in this study. The CBR mould of a volume of $2305 \mathrm{~cm}^{3}$ and 4.5 $\mathrm{kg}$ rammer with a drop height of $450 \mathrm{~mm}$, applied on five layers of soil, at 27 blows per layer was used as the compactive effort. The optimum moisture content obtained from compaction test was used to prepare the soil for the CBR test as set out in [18]. The CBR mould $\left(2305 \mathrm{~cm}^{3}\right)$ and $4.5 \mathrm{~kg}$ rammer were used, 5 layers of the soil were compacted with 62 blows applied on each layer. The test was carried out about 15 minutes after the compaction. The CBR test was performed on the unsoaked and the 24 hours soaked samples. The percentage of swell and the difference in weight of the soaked samples were calculated after the soaking period.

\subsubsection{Cement Quantity Selection Procedure for Blends}

Cement quantity selection procedure set out in [19] was applied. Fixed quantities of DCA (5\%), sand (10\% and $20 \%$ ) and lateralite (5\%) by weight of the soil were used. Soil-DCA and soil-sand composites were blended with $5 \%, 10 \%$ and $15 \%$ cement by weight of the soil, and soillateralite composite was blended with $3 \%, 5 \%$ and $7 \%$ cement also by weight of the soil. A 24 hours soaked CBR value of about $20 \%$ was carried out in the laboratory test. This was obtained by plotting a linear graph of 24 hours soaked CBR of the stabilised composites against cement quantities. Equations generated were used to calculate the cement contents that would give 20\% soaked CBR value. This procedure gave probable blends that could be adopted as the subgrade, and these were further tested by soaking for 96 hours and their CBR values obtained. A minimum soaking period of 4 days (96 hours) is specified in [18]. This typified flooding or elevation of water table the stabilised soil might be subjected to in the field. A reduction of not more than $50 \%$ after 96 hours soaking was targeted. The results of tests performed are presented in Tables 2, 3, and 4.

\section{RESULTS AND DISCUSSION}

\subsection{Classification Characteristics}

The Physico-chemical properties of the stabilising agents are presented in Table 1. The specific gravity of cement was 3.02 , lateralite was 2.44 while DCA had the least value of 1.54 . The initial setting time of cement occurred at 105 mins and final setting time took place within 4 hours of the start of test. Both lateralite and DCA had initial setting time beyond the specified lower limit of 75 mins for pozzolanic cement [20].

The ratio by mass of $\mathrm{CaO}$ to $\mathrm{SiO}_{2}$ was 1.3 in both lateralite and DCA, and also had low calcium oxide when compared with cement. Specification in [20] for ratio $\mathrm{CaO} / \mathrm{SiO}_{2}$ was $\geq 2$, and calcium oxide ranging from $61-67 \%$ for cementitious binders. Therefore, both lateralite and DCA lacked the attributes to be labelled as cementitious materials. Materials having $\mathrm{CaO} / \mathrm{SiO}_{2}$ greater than 1 are specified as 'off specification' pozzolanas [21]. Although both DCA and lateralite could not initiate a cementing reaction, their $\mathrm{pH}$ values which was comparable with cement indicated that they can take part in pozzolanic reactions.

Table 1: Physico-chemical Properties of Cement, DCA, and Lateralite

\begin{tabular}{llll}
\hline Properties & $\begin{array}{l}{ }^{*} \text { Cement } \\
(42.5 \mathrm{R})\end{array}$ & DCA & Lateralite \\
\hline Specific gravity & 3.02 & 1.54 & 2.44 \\
Initial setting time (min) & 105 & $>300$ & $>300$ \\
Final setting time (min) & 240 & $>375$ & $>375$ \\
$\mathrm{pH} @ 23.5^{\circ} \mathrm{C}$ & $12-13$ & 12.00 & 12.2 \\
$\mathrm{SiO}_{2}(\%)$ & 19.96 & 19.30 & 23.2 \\
$\mathrm{Fe}_{2} \mathrm{O}_{3}(\%)$ & 2.99 & 7.24 & 6.70 \\
$\mathrm{Al}_{2} \mathrm{O}_{3}(\%)$ & 6.05 & 5.52 & 6.67 \\
$\mathrm{CaO}$ & 64.86 & 25.60 & 30.80 \\
$\mathrm{MgO}$ & 1.26 & 0.72 & 3.67 \\
$\mathrm{SO}_{3}$ & 1.99 & - & - \\
$\mathrm{K}_{2} \mathrm{O}$ & 1.09 & - & - \\
$\mathrm{Na}_{2} \mathrm{O}$ & - & - & - \\
$\mathrm{P}_{2} \mathrm{O}_{3}$ & 0.24 & - & - \\
$\mathrm{LOI}$ & 7.84 & - & - \\
$\mathrm{Not}$ detected & - & 41.62 & 16.76 \\
\hline
\end{tabular}

${ }^{*}$ Oxides content obtained from [22]

The particle size distribution (PSD) curve in Figure 3 shows that the fat clay was predominantly a fine-grained soil, consisting substantial amount of silt and clay (P063 was $85.48 \%$ ), and was devoid of any gravel and coarse sand. Based on its consistency limits (Table 2), the soil can be classified as A-7-6 using AASHTO classification and $\mathrm{CH}$ using USCS classification system. Thus, the soil was a fat clay of poor subgrade rating. The white sand which was used for re-grading had less than $1 \%$ particles that passed through sieve $63 \mu \mathrm{m}$, and more than $97 \%$ particles passed through sieve $2.36 \mu \mathrm{m}$. A large portion of its curve lies between 0.1 and $1.0 \mathrm{~mm}$ particle sizes on 
the graph and the Coefficient of curvature (Cc) was $\sim 1$. Also, Coefficient of uniformity $(\mathrm{Cu})$ was 3 , which was less than 6 for well graded sand as specified in USCS. Therefore, the sand was uniformly graded containing substantial amount of intermediate particle sizes. Blending of $10 \%$ sand with fat clay gave a better particle size distribution by reducing P063 to $\sim 42 \%$. The construction practice in the region was to place the sand as fill and surcharge material, without blending with the in-situ subgrade.

The unstabilized fat clay and stabilized blends in Table 2 had their liquid limits and plasticity indices within the specified limits of $50 \%$ and 30 respectively [17]. However, the linear shrinkage of the soil was above the specified limit of $6 \%$ [23]. Addition of blends of sand-PC, DCA-PC and lateralite-PC caused improvement in this property; the higher the cement content the lower the linear shrinkage.

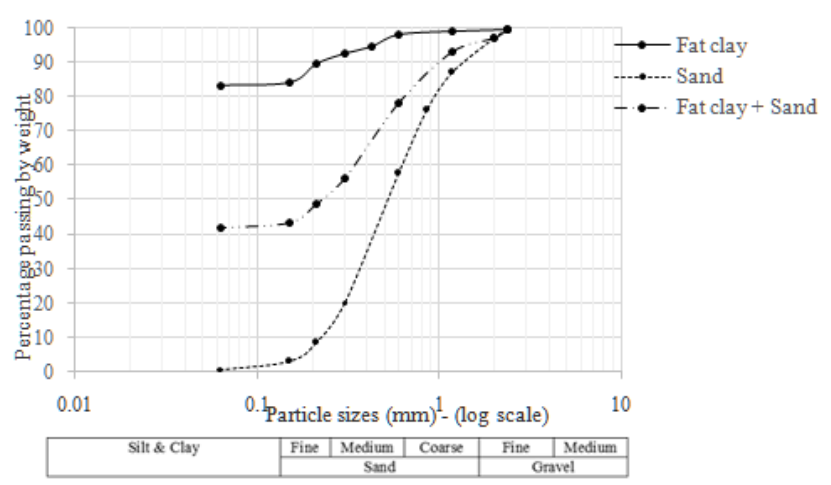

Figure 3: Re-grading of the fat clay with uniformly graded sand

\subsection{Generic Strength Characteristics of Stabilised Blends}

Blending of $10 \%$ sand with the soil gave better unsoaked and soaked CBR of $3.41 \%$ and $1.38 \%$ respectively. These results agreed with the report by [6] which stated that addition of controlled sand proportions to marginal deltaic soils prior to compaction improved strength. Similar improvement was obtained when 5\% DCA and $5 \%$ lateralite were used to stabilise the soil. Substantial increase in 24 hours soaked CBR compared with the unsoaked CBR was obtained for all the blends containing cement. This could be attributed to adequate hydration of cement during soaking that effected increase in strength. However, swelling was also noted in composites containing $10 \%$ sand (in Table 2), therefore the sand content was increased to $20 \%$ with the same incremental quantity of cement. All the tests were repeated and results presented in Table 3. As noted before, there was increase in unsoaked and 24 hours soaked CBR of the stabilised blends when compared with the unstabilised clay. Although the values were not as high as those obtained for blends containing $10 \%$ sand, but there was decrease in swell.

Design mixes that could be adopted for subgrade stabilisation are presented in Table 4. The compaction, strength, and swell characteristics of these blends were compared with those of the unstabilised fat clay, and discussed in subsequent sections.

\subsection{Compaction Characteristics}

Figure 4a - c show the dry density/moisture content relationship curves and the zero air void (ZAV) lines for the unstabilised fat clay and the design-blends for subgrade application. The unstabilised fat clay had higher MDD than the stabilised composites (soil-DCA-PC, soil-sand-PC, and soil-lateralite-PC), although, its ZAV line which touches the compaction curve revealed that not all the air voids could be eliminated. The lower MDD of the design-blends could be attributed to higher quantity of water required for lubrication of noncementing particles and hydration of PC. However, as PC content is increased, the corresponding increase of MDD could be attributed to cementation or hardening effect of PC on soil particles. Also, as PC content was increased, increase in MDD and decrease in OMC were obtained for all the blends. The ZAV lines were tangential to the compaction curves of the stabilised blends, and this indicated that full saturation was obtained for the soilblends.

\subsection{Strength Characteristics}

The relatively high MDD of the unstabilised fat clay was not reflected on the unsoaked and soaked CBR of $0.56 \%$ and $0.38 \%$ respectively. This revealed that although high densification was obtained with the West African compaction, this did not result in corresponding improvement of its bearing capacity. However, substantial improvement in the CBR of the fat clay soil was obtained with the design-blends (Figure 5). The targeted 24 hours soaked CBR of $20 \%$ was obtained with the following blends (with ratios in bracket): $5 \%$ DCA $+4.5 \%$ PC - (1:1); $20 \%$ sand +5\% PC - (4:1); and 5\% lateralite $+3 \% \mathrm{PC}-(2: 1)$. The 24 hours soaked $\mathrm{CBR}$ value of these blends showed that DCA-PC was $83 \%$ more than its unsoaked value, soaked sand-PC value was $48 \%$ more while soaked lateralite-PC was $152 \%$ more than its unsoaked CBR. Furthermore, these blends exhibited commendable stability after complete soaking in water for 96 hours. The reduction in their soaked CBR values between 24 and 96 hours was not more than 50\%.

\subsection{Swell Characteristics}

Swell test was an indicator of the expansion potential of a soil on contact with water. Expansive clay minerals and sulphates can react with cementitious matrix of 
stabilised materials in the presence of excess water, and cause expansion to occur after compaction. Therefore, [24] recommended an average swell limit value of $5 \mathrm{~mm}$ dial gauge reading (which is $\sim 4 \%$ for sample compacted in a CBR mould), which should not be greater than $10 \mathrm{~mm}$ during the soaking period. Values ranging from $0.002-$ $0.008 \%$ were obtained in this study for the design-blends (shown in Figure 6). This revealed that swell was not substantial for these composites.

Table 2: First Trial Composites to Determine Cement Quantity Requirement

\begin{tabular}{|c|c|c|c|c|c|c|c|c|c|c|c|c|c|}
\hline \multirow[b]{2}{*}{ Properties tested } & $\begin{array}{c}\text { Soil } \\
\text { (Fat clay) }\end{array}$ & \multicolumn{4}{|c|}{$\begin{array}{c}\text { Soil + } \\
\text { DCA + Cement } \\
\end{array}$} & \multicolumn{4}{|c|}{$\begin{array}{c}\text { Soil + } \\
\text { Sand + Cement }\end{array}$} & \multicolumn{4}{|c|}{$\begin{array}{c}\text { Soil + } \\
\text { Lateralite + Cement }\end{array}$} \\
\hline & & $\begin{array}{l}\text { Soil + } \\
5 \% \\
\text { DCA } \\
\text { only }\end{array}$ & $\begin{array}{l}\text { Soil + } \\
5 \% \\
\text { DCA } \\
+ \\
5 \% \\
\text { PC } \\
\end{array}$ & $\begin{array}{l}\text { Soil + } \\
5 \% \\
\text { DCA } \\
+ \\
10 \% \\
\text { PC } \\
\end{array}$ & $\begin{array}{l}\text { Soil + } \\
5 \% \\
\text { DCA } \\
+ \\
15 \% \\
\text { PC } \\
\end{array}$ & $\begin{array}{l}\text { Soil + } \\
10 \% \\
\text { sand } \\
\text { only }\end{array}$ & $\begin{array}{l}\text { Soil + } \\
10 \% \\
\text { sand } \\
+ \\
5 \% \\
\text { PC } \\
\end{array}$ & $\begin{array}{l}\text { Soil + } \\
10 \% \\
\text { sand } \\
+ \\
10 \% \\
\text { PC } \\
\end{array}$ & $\begin{array}{l}\text { Soil + } \\
10 \% \\
\text { sand } \\
+ \\
15 \% \\
\text { PC }\end{array}$ & $\begin{array}{l}\text { Soil + } \\
5 \% \\
\text { lat } \\
\text { only }\end{array}$ & $\begin{array}{l}\text { Soil + } \\
5 \% \\
\text { lat } \\
+ \\
3 \% \\
\text { PC } \\
\end{array}$ & $\begin{array}{l}\text { Soil + } \\
5 \% \\
\text { lat } \\
+ \\
5 \% \\
\text { PC } \\
\end{array}$ & $\begin{array}{l}\text { Soilt+ } \\
5 \% \\
\text { lat } \\
+ \\
7 \% \\
\mathrm{PC} \\
\end{array}$ \\
\hline P063 & 85.48 & - & - & - & - & - & - & - & - & - & - & - & - \\
\hline Liquid Limit (\%) & 50.12 & 44.54 & 36.95 & 30.33 & 28.85 & 34.58 & 30.03 & 39.16 & 41.74 & 45.52 & 42.41 & 44.23 & 34.01 \\
\hline Plastic Limit (\%) & 20.80 & 21.88 & 22.34 & 22.50 & 23.40 & 23.19 & 21.92 & 30.23 & 31.88 & 27.76 & 26.04 & 28.38 & 25.55 \\
\hline Plasticity Index & 29.32 & 22.66 & 14.61 & 7.83 & 5.45 & 11.39 & 8.11 & 8.93 & 9.86 & 17.76 & 16.37 & 15.85 & 8.46 \\
\hline Linear Shrinkage (\%) & 13.22 & 13.57 & 5.79 & 2.46 & 2.14 & 5.92 & 9.47 & 4.21 & 4.00 & 11.43 & 4.83 & 4.82 & 4.29 \\
\hline $\operatorname{MDD}\left(\mathrm{kg} / \mathrm{m}^{3}\right)$ & 1712 & 1845 & 1620 & 1633 & 1640 & 1686 & 1678 & 1710 & 1676 & 1540 & 1589 & 1610 & 1640 \\
\hline OMC (\%) & 19.18 & 10.5 & 15 & 17.5 & 14 & 16 & 14.5 & 12.5 & 15.35 & 20 & 18 & 18 & 18 \\
\hline CBR \% - Unsoaked & 0.56 & 31.94 & 5.16 & 2.46 & 1.23 & 3.41 & 8.17 & 24.68 & 56.62 & 4.91 & 7.89 & 12.65 & 2.00 \\
\hline CBR \% - Soaked (24 hrs) & 0.38 & 5.76 & 47.60 & 73.65 & 67.05 & 1.38 & 40.08 & 120.24 & 117.49 & 6.66 & 43.59 & 56.61 & 44.59 \\
\hline Swelling \% & Eroded & 1.87 & 0.046 & 0.002 & 0 & Eroded & 0.002 & 0.003 & 0.039 & 0.012 & 0.024 & 0.024 & 0 \\
\hline
\end{tabular}

P063 = Percentage passing sieve $63 \mu \mathrm{m}$; DCA = Drill cuttings ash; lat = lateralite; PC = Portland limestone cement

Swelling \% was taken as the ratio of swell reading from the dial gauge to the height of the CBR mould

Table 3: Second trial mixes of soil-sand-cement blends

\begin{tabular}{c|c|c|c}
\hline & Soil + & Soil + & $\begin{array}{c}\text { Soil + } \\
20 \% \text { Sand }+ \\
15 \% \text { PC }\end{array}$ \\
\hline Properties tested & $20 \%$ Sand + & $20 \%$ Sand + & 37.48 \\
& $5 \%$ PC & $36 \%$ PC & 27.09 \\
Liquid Limit (\%) & 36.32 & 26.33 & 10.39 \\
Plastic Limit (\%) & 23.89 & 10.47 & 5.82 \\
Linear Shrinkage (\%) & 12.43 & 6.83 & 1664 \\
MDD (kg/m $\left.{ }^{3}\right)$ & 7.37 & 1640 & 16.85 \\
OMC (\%) & 1685 & 14 & 9.52 \\
CBR \% - Unsoaked & 14 & 10.53 & 54.61 \\
CBR \% - Soaked (24 hrs) & 7.74 & 39.08 & 0 \\
Swelling \% & 20.92 & 0.002 & \\
\hline
\end{tabular}

Table 4: Design blends - probable blends for subgrade application

\begin{tabular}{|c|c|c|c|c|c|c|c|}
\hline \multirow[t]{2}{*}{ Properties tested } & \multicolumn{2}{|c|}{$\begin{array}{c}\text { Soil + DCA + } \\
\text { Cement }\end{array}$} & \multicolumn{3}{|c|}{$\begin{array}{c}\text { Soil + Sand + } \\
\text { Cement }\end{array}$} & \multicolumn{2}{|c|}{$\begin{array}{c}\text { Soil + Later + } \\
\text { Cement }\end{array}$} \\
\hline & $\begin{array}{c}\text { Soil + } \\
5 \% \\
\text { DCA } \\
+ \\
3.5 \% \\
\text { PC }\end{array}$ & $\begin{array}{c}\text { Soil + } \\
5 \% \\
\text { DCA } \\
+ \\
4.5 \% \\
\text { PC }\end{array}$ & $\begin{array}{c}\text { Soil + } \\
10 \% \\
\text { Sand } \\
+ \\
2.2 \% \\
\text { PC }\end{array}$ & $\begin{array}{c}\text { Soil + } \\
10 \% \\
\text { Sand } \\
+ \\
3 \% \\
\text { PC }\end{array}$ & $\begin{array}{c}\text { Soil + } \\
20 \% \\
\text { Sand } \\
+ \\
5 \% \\
\text { PC }\end{array}$ & $\begin{array}{c}\text { Soil + } \\
5 \% \\
\text { Later } \\
+ \\
2.3 \% \\
\text { PC }\end{array}$ & $\begin{array}{c}\text { Soil + } \\
5 \% \\
\text { Later } \\
+ \\
3 \% \\
\text { PC }\end{array}$ \\
\hline Liquid Limit (\%) & 45.85 & 42.98 & 43.31 & 38.82 & 36.32 & 47.29 & 43.73 \\
\hline Plastic Limit (\%) & 23.50 & 27.05 & 25.72 & 26.98 & 23.89 & 28.58 & 24.06 \\
\hline Plasticity Index & 22.35 & 15.93 & 17.59 & 11.84 & 12.43 & 18.71 & 19.67 \\
\hline Linear Shrinkage (\%) & 11.00 & 10.05 & 11.07 & 10.00 & 7.37 & 9.07 & 3.57 \\
\hline $\operatorname{MDD}\left(\mathrm{kg} / \mathrm{m}^{3}\right)$ & 1530 & 1540 & 1524 & 1570 & 1685 & 1470 & 1530 \\
\hline OMC (\%) & 21.5 & 20 & 17.5 & 17 & 14 & 25 & 17.5 \\
\hline CBR \% - Unsoaked & 5.96 & 11.15 & 5.21 & 6.01 & 15.53 & 6.62 & 10.32 \\
\hline CBR \% - Soaked (24 hrs) & 16.29 & 20.42 & 6.62 & 12.90 & 22.92 & 16.91 & 26.05 \\
\hline CBR \% - Soaked (96 hrs) & 8.27 & 16.16 & 6.25 & 11.28 & 10.02 & 15.53 & 16.53 \\
\hline Swelling \% & 0.004 & 0.004 & 0.031 & 0.030 & 0.002 & 0.003 & 0.008 \\
\hline
\end{tabular}




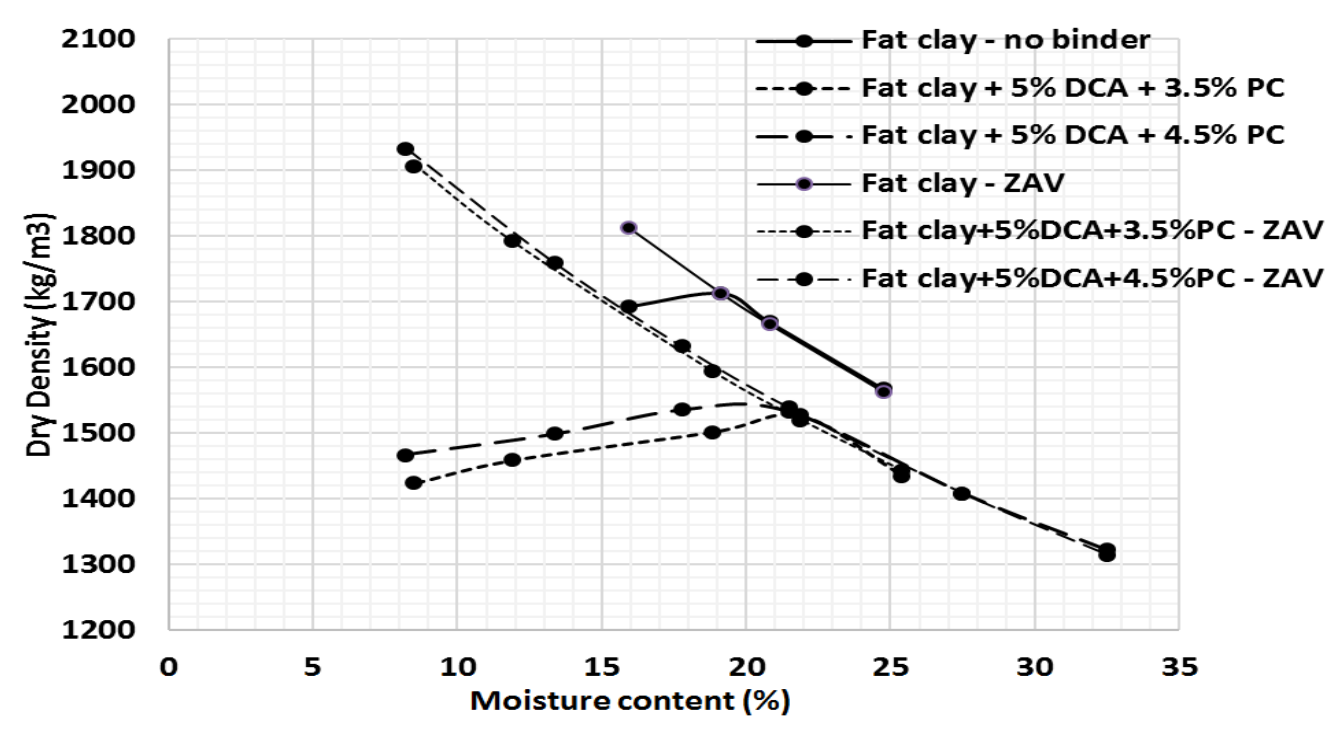

(a)

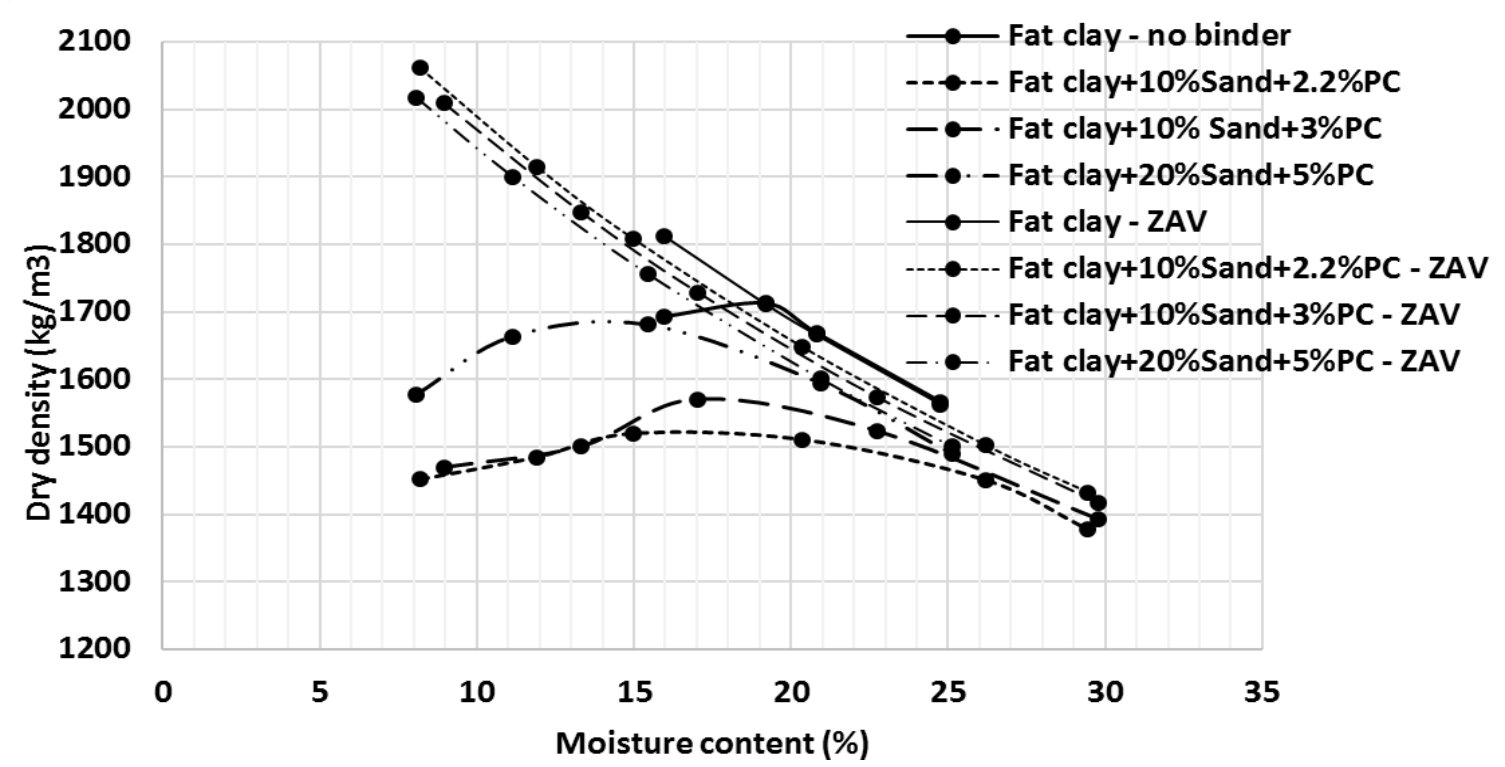

(b)

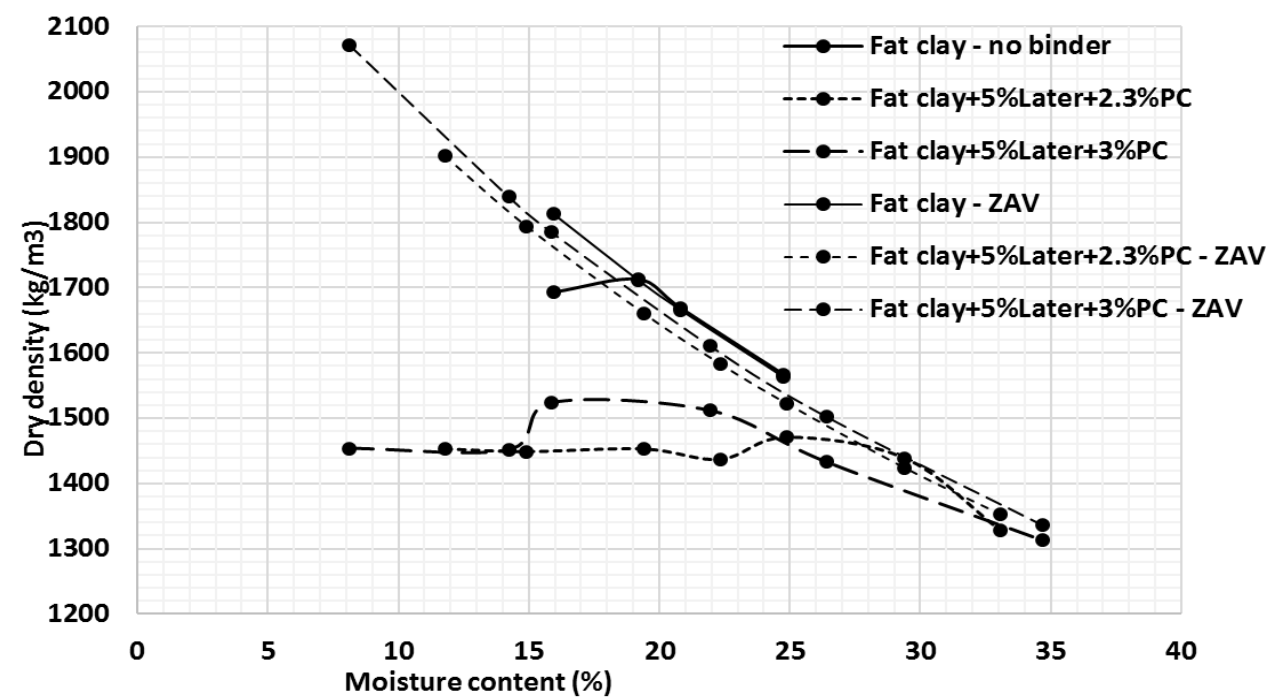

Figure 4: Compaction curves of the fat clay and the design-blends - (a): Soil-DCA-PC blend; (b): Soil-Sand-PC blend; (c): Soil-Lateralite-PC blend 


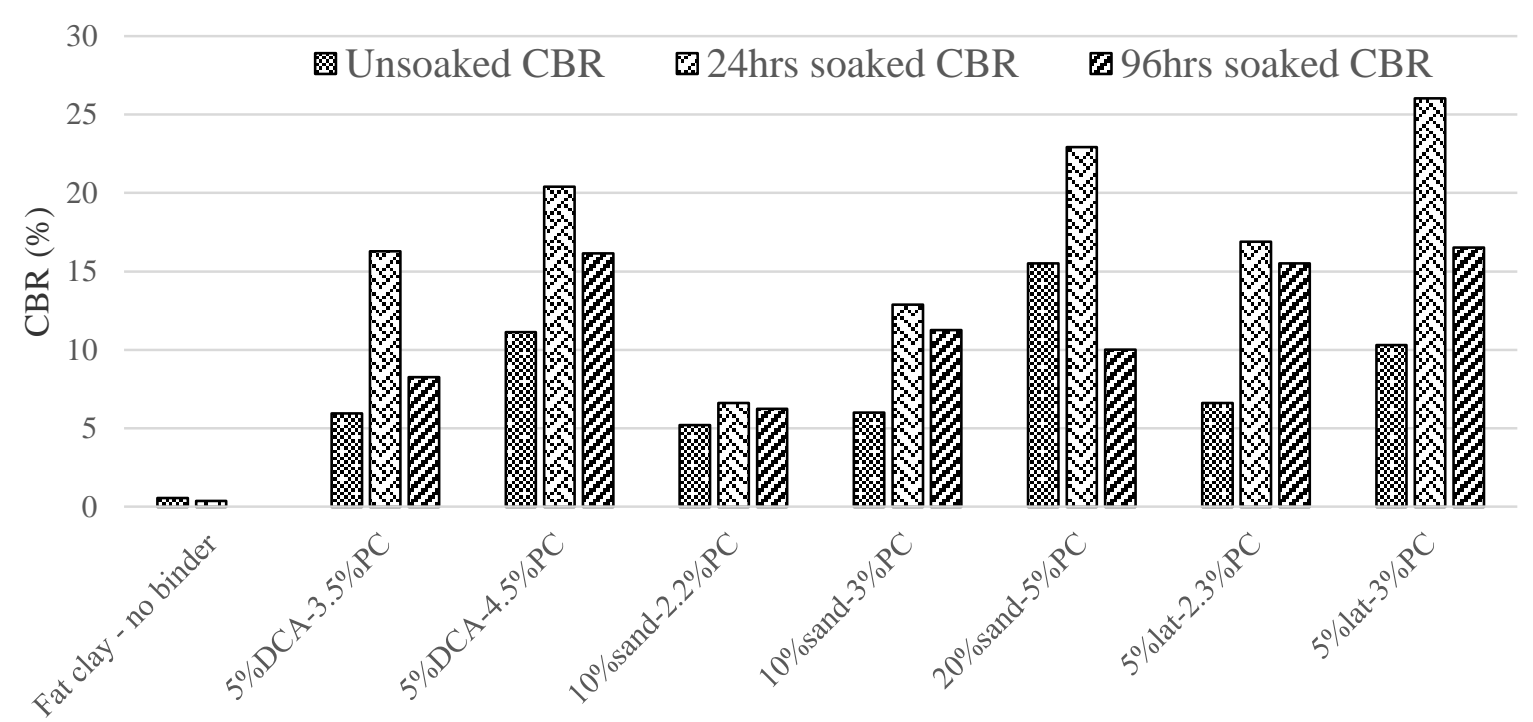

Figure 5: Effect of blends on the unsoaked and soaked CBR of the fat clay

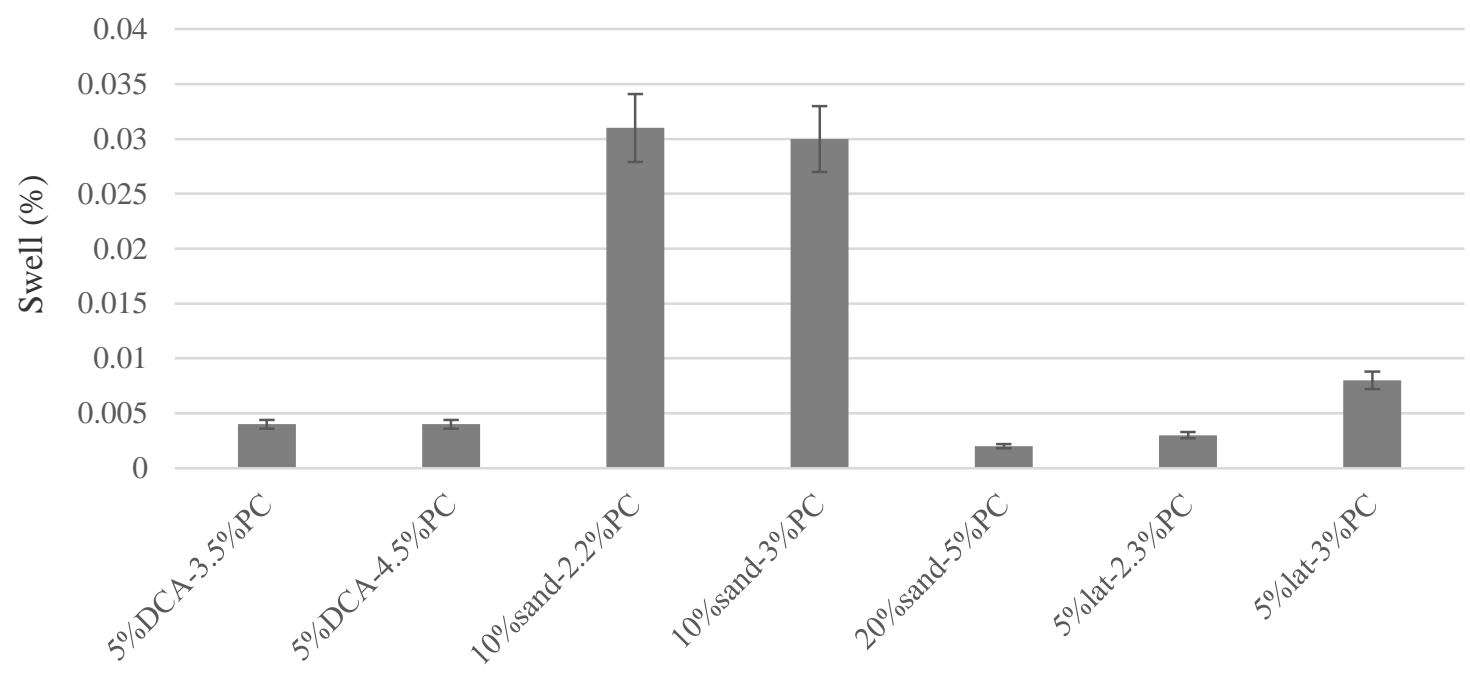

Figure 6: Effect of blends on the swell of the fat clay

\section{CONCLUSION}

From the results obtained from the analysis of the unstabilised fat clay and the stabilised blends, the following conclusions are made:

1) The unstabilised fat clay was fine-grained, with high swelling potential, and had low CBR value, therefore the soil is an unsuitable subgrade material.

2) Sand, DCA, and lateralite effected improvements in the gradation and plasticity of the soil, and cement enhanced its bearing capacity.

3) Blends ratio: sand-PC (4:1); DCA-PC (1:1); and lateralite-PC (2:1) adequately stabilised the fat clay, which was noted in the CBR and swell values.
4) Therefore, the stabilisedfat clay composites can be adopted as subgrade materials.

\section{REFERENCES}

[1] Otoko, G. R. and Blessing, O. C. "Cement and Lime Stabilisation of Nigerian Deltaic Marine Clay (Chikoko)", European Int. Jour, of Sci. and Tech. Vol. 3, No. 4, pp. 53 - 60, 2014.

[2] Ekeocha, N. E. and Akpokodje, E. G. "Cement Stabilisation Characteristics of Shale Subgrade of Parts of the Lower Benue Trough, Southeastern Nigeria" IJST, Vol. 3. No. 1,pp. 78 - 84, 2014.

[3] Little, D. N. and Nair, S. "Recommended Practice for Stabilisation of Subgrade Soils and Base Material: NCHRP 144", Transportation Research Board of the 
National Academies, 2009.

[4] Akpokodje, E. G. "A Method of Reducing the Cement Content of Two Stabilized Niger Delta Soils", Quarterly Journal of Engineering Geology,Vol. 19, pp. $359-363,1986$.

[5] Eze, E. O. and Suoware, O. P. "Geotechnical Evaluation of Untreated and Cement-treated Ajali Sandstone from Southeastern Nigeria" Quarterly Journal of Engrg. Geol., 26,pp. 137 - 148, 1993.

[6] Omotosho, 0. and Eze-Uzomaka, 0. J. "Optimal Stabilization of Deltaic Laterite", Institution of Civil Engineering, Technical Paper. Vol. 50, No. 2, pp. 10 17. 2008.

[7] Joel, M. and Agbede, I. O. "Mechanical-Cement Stabilisation of Laterite for Use as Flexible Pavement Material", ASCE, Journal of Materials in Civil Engineering, pp. $146 \quad$ - 152. (http://www.ascelibrary.org at Cambridge University), assessed on August, 2012. 2011.

[8] Bone, B. D., Barnard, L. H., Boardman, D. I., Carey, P. J., Hills, C. D., Jones, H. M., MacLeod, C. L. and Tyrer, M. "Review of Scientific Literatures on the Use of Stabilisation/Solidification for the Treatment of Contaminated Soil, Solidwaste and Sludges". Science report SC 980003/SR2. Environmental Agency UK, 2004.

[9] Sherwood, P. T. "Soil stabilisation with cement and lime. State of the art review", Transport 332 Research Laboratory, HMSO, pp. 140 - 147. 333, 1993.

[10] Niger Delta Development Commission "Niger Delta Regional Development Master Plan Chapter 1: Niger Delta Region, Land and People". (www.nddc.gov.ng), assessed on August, 2015.

[11] Akpokodje, E. G. "The Engineering - Geological Characteristics and Classification of the Major Superficial Soils of the Niger Delta". Engineering Geology, Vol. 23, pp. 193 - 211. 1987.

[12] Meshida, E. A. "The Evolution of a New Flux for Stabilising Fine-grained Lateritic Soils", Terra Geotech. Eng. Ltd. Lagos. Research paper No. 8, pp. 1 - 12. 2001.

[13] BS EN 196-3 “Methods of Testing Cement.
Determination of Setting Times and Soundness",British Standards Institution, London, 2005.

[14] BS 1377: Part 2 "Methods of test for Soils for Civil Engineering Purposes: Classification tests",British Standards Institution, London, 1990.

[15] Netterberg, F. "Review of Specifications for the use of Laterites in Road Pavement" (Contract: AFCAP/GEN/124). Crown agents, AFCAP and UKaid, 2014.

[16] BS 1924 "Stabilised Materials for Civil Engineering Purposes Parts 1 and 2".British Standards Institution, London, 1990.

[17] Federal Ministry of Works and Housing "Highway Manual Part 1 - Road Design", Federal Republic of Nigeria. 1972.

[18] BS 1377: Part 4 ."Methods of test for Soils for Civil Engineering Purposes: Compaction-related tests", British Standards Institution, London, 1990.

[19] BS 6543 (1985). "Guide to Use of Industrial Byproducts and Waste Materials in Building and Civil Engineering", British Standards Institution, London.

[20] BS EN 197-1 (2000). "Cement - Part 1: Composition, Specifications and Conformity Criteria for Common Cements", British Standards Institution, London.

[21] Bin-Shafique, S., Edil, T., Benson, C., and Senol, A.. "Incorporating a fly-ash stabilised layer into pavement design", Proceedings of ICE, Geotechnical Engineering, Vol. 157 No. GE4, pp. 239 - 249, 2004.

[22] Ibrahim, H. H., Birnin-Yauri, U. A., Muhammad, C. and Umar, A. "Assessment of Pollution Potentialities of Some Portland cement", Nigerian Journal of Basic and Applied Science NJBAS, 20(2): 182-184, 2012.

[23] Dreyfus, J. "Laterites" Rev. Gen. Routes Aerodromes 22 (245): pp 88 - 100. In: Gidigasu, M. D. "Laterite soil Engineering: Pedogenesis and Engineering Principles", Elsevier Scientific Publishing Company, Amsterdam Oxford, New York. 554pp, 1976.

[24] Sherwood, P. T. "Stabilised capping layers using either lime or cement, or lime and cement". Contractor report CR 151, TRL Limited., 1992. 